\title{
Research on reasons and effects of compensation control on executives of state-owned enterprises
}

\author{
Jiawu Gan \\ International Business School \\ Yunnan University of Finance and Economics \\ Kunming, China \\ andy_gan@ynufe.edu.cn
}

Ming Li*

International Business School

\author{
Yunnan University of Finance and Economics \\ Kunming, China \\ 839772415@qq.com
}

Xin $\mathrm{Li}$

International Business School

Yunnan University of Finance and Economics

Kunming, China

lizzydizzy@sina.com

\begin{abstract}
There has been controversies on the sky-high compensation of state-owned enterprise(SOE) executives over the years; and the Ministry of Finance issued a series of governmentimposed pay curbs on their compensation to limit the pay of the state-owned enterprise executives. However, the effect of such regulations are difficult to assess. Based on the literature research, possible effects by the limit pay order are probed into, then the underlying reasons are analyzed, and then the corresponding consequences are discussed. and in the end reasonable and feasible suggestions put forward.
\end{abstract}

Keywords-executive compensation; limit pay order; SOE executives;

\section{INTRODUCTION}

With the sky-high compensation news as China's Ping An insurance Company's chairman Ma Mingzhe keeps alive in the media over the years, rising executive compensation received constant concern and triggered hot debate and discussion among people from all walks of life. One can not help asking whether executive compensation levels are too high and whether their compensation is corelative to their performance. To this end, the government issued many administrative regulations to regulate executive compensation of state-owned enterprises: in 2002 the provisions of the SASAC, the central enterprises executive compensation shall not exceed 12 times the average wage of workers; in 2009 the central six ministries jointly issued "On Further Regulating the Executive Compensation of central SOEs (hereinafter referred to as" the "compensation limit order"); in the period of NPC and CPPCC of 2013, the State Council approved "On Deepening the Reform of Income Distribution System" focus on the reform of compensation reform of SOEs' executives; in 2014 the government promulgated the "Reform Plan of the Compensation System of the Executives in central SOEs" to strengthen the interrelations between compensation and performance. The compensation limit aims at regulating the executive compensation to optimize its structure with proper standard and normative management. However, the efficiency of the "compensation limit order" is still under explored, then, what are the economic significance of the government's limit order? What impact will it have on the executive behavior of state-owned enterprises? Based on the profound analysis of the causes and effects of the compensation limited order, thoughts and suggestions are put forward through theoretical analysis and practical summary.

\section{ANALYSIS OF THE COMPENSATION CONTROL ON EXECUTIVES OF SOES}

When it comes to compensation control(compensation limit order), we should start with relevant literature on regulation economics. The study of regulation in the West has gone through two stages: "the theory of public interest" and "the theory of interest groups". The former affirms the role of regulation as a viable means of eliminating market inefficiencies, but this view is criticized by a number of empirical literature, and most of the literature supports the view that regulation demand arises from interest groups controlling power. So, why are the public so sensitive to the current state executives' compensation? And Why should the government control it? This paper argues that the public doubt about the ability of executives of SOEs whose position is appointed by the administrate government in disregard of the selecting mechanism of the market; and nature of multi-tasks and monopoly of SOEs further blurred the degree of contribution by the executives. In addition, there are many problems in the governance structure of state-owned enterprises. All these have lowered public expectations of executive pay for state-owned enterprises. From the above two theories, reasons for the compensation control of executives of SOEs in china is to be analyzed.

First of all, executives of SOEs is appointed by the administrative government instead of the competition mechanism-laws of "survival of the fittest" of the market. The executives selected from the cadre of the government officials are most likely to lack rich management experience and talent, only to fulfill the political promotion mindset of "obeying organization and accomplishing assignment", which is in sharp difference with the talent required in genuine professional

*Corresponding author 
executives, and thus their compensation should not be on the same level. Thinking. Therefore, the uncertainty of state-owned enterprise executives' identity is the fundamental reason why their compensation are questioned.

Secondly, the fairness preference is the direct reason for government compensation regulation, because the government is pursuing the maximization of public interests rather than the maximum value of the enterprise Further study finds that the government preference in incentive practice of SOEs are obvious; excessive executive compensation will discontent employees as well as the public and even disrupt the social stability [1]. Based on the theory of "unfair preference" of clients, Wang and Wei believe that in exploring and implementing compensation incentive plans, excessive income gap would trigger potential social pressure [2].Conclusion can be drawn from here that the government's preference in the initial distribution of state-owned enterprises is the direct cause of compensation control.

Thirdly, the administrative intervention in SOEs further blurs the relationship between executives and enterprise performance, so it is difficult to formulate compensation according to the management efficiency of top managers of non-state-owned enterprises. It is difficult to evaluate the degree of correlation between the performance of SOEs and the ability of the executives. Their managing ability and compensation level, therefore are being questioned by the public..

Finally, the relating mechanism of restriction and supervision of state-owned enterprises is far from perfect, exposed mainly in the corporate governance structure : property right is not clear without a clear line between the functions of the government and that of the enterprises; the capital market remains undeveloped and the managers market lags far behind. In recent years, although modern enterprise system has been established in SOEs as the goal of reform, the gaps with a comparatively thoroughly internal control oriented governance pattern still exists, and not a small one. Firstly, hierarchical entrustment of agents agent and unclear property right, along with other reasons make the investors of SOEs absent and without clear and definite principles as owners to exercise rights and perform duties; Secondly, different from thorough internal control and mature management mode, although the bank has larger investments in SOEs, the supervision upon which is far from enough. Finally, the board of Chinese state-owned enterprise is not in the true sense of the board of directors because of the dominance of state-owned shareholders with most of the functions and powers of the board of director replaced by the government, expanding the information asymmetry between principals and agents further.

\section{ECONOMIC EFFICIENCY ANALYSIS OF EXECUTIVES' COMPENSATION IN SOES}

At present, the academic research on the effect of "limited pay order" is still relatively insufficient. Most of these studies focus on the ineffectiveness of compensation limits, which would even lead to corruption and lower corporate performance of executives. A small number of research hold that the on-the-job consumption caused by limited compensation serves as a driving force to improve the efficiency of executives. It is a kind of incentive mode, which is equivalent to monetary incentive, and has a positive effect.

Up till the present, most research on the compensation regulation are combined with on-the-job consumption of executives with conclusions that regulations lead to more serious on-the-job consumption problem. Most scholars believe this on-the-job consumption is a kind of agency problem: in the pursuit of self-interest maximization, executives deviate from enterprise's profit maximization as part of the cost of agency caused by the combination of imperfect external supervision system and the overpower of internal managers. These theories of agency believe government compensation control on executives may be ineffective and even unnecessary at all.

Jensen and Meckling stressed that on-the-job consumption is essentially a proxy conflict between management and external shareholders with negative economic consequences in reducing the value of the enterprise; if management can choose the level of subsidy freely without supervision, they will increase their non monetary benefits to maximize their own utilities: if they hold less shares of the enterprise, they assume less cost in the non-monetary consumption and thus incline to enjoy more non-monetary benefits [4]. Chen and others found that job consumption has become an alternative incentive source for executives of SOEs under compensation control; when compared with private enterprises, the incentive compensation efficiency of SOEs is inadequate [5]. Wan and Chen also found that the compensation control may be limited to monetary payment only, and the possibility of executive corruption increases along with the control.[3]. Shen and Li 's empirical research selected compensation samples of 6871 executives in China's listed companies from the year of 2005 to 2009 , found out that "compensation limit order" did not reduce the level of payment of executives but increase dramatically instead, "compensation luck phenomenon" kept existing and the limit did not achieve expected effect [6]. Wang and Zhu' s findings support the research done by Shen and $\mathrm{Li}$ [7]. $\mathrm{Xu}$ 's studies confirm that China's manager market, especially the manager market of SOEs, are still subject to government regulation, especially in the implementation of government policy to strictly limit the compensation of executives; when this market inefficiency compensation mechanism operates, executives seek alternative compensation for incentives as on-the-job consumption, corruption, bribery, embezzlement and other acts of corruption for personal gain [9]. Wang found that compensation regulation directly reduce corporate performance, and through the "anchor effect", executive behavioral choices are affected, making on-the-job consumption as an alternative compensation. At the same time, salary control will not only lead to corruption problems as onthe-job consumption, but also further reduce corporate performance [2]. Xu found that the government compensation regulation results in the increase of executives' invisible income, which significantly reduced the value of the company [8]. The empirical results by Chen show that the compensation control of SOEs makes the compensation arrangements lack incentive efficiency, while on-the-job consumption exerts a significantly negative effect on corporate performance [10]. To summarize, agency costs are in fact trigger conflicts between 
owners and managers of enterprises, and the compensation control on executives severe the conflicts through executives compensation seeking for their own interest, so as to increase the cost of business operations, thereby reduce corporate performance.

Different form these theories of agency, a small percentage of scholars hold the view of efficiency. They believe in on-thejob consumption by holding it as a driving force to increase management efficiency, as a kind of incentive mode equivalent to monetary incentive with a positive effect. Rajan and Wulf carry out a distinctive research to raise "efficiency theory" through a systematic review on on-the-job consumption, proposing its necessity because it improves production efficiency, which is different from previous studies [11]. Henderson and Spindler give another positive meaning of onthe-job consumption from the perspectives of employee savings and enterprise dependence. They argue that too much money and employee savings lower their dependence on enterprises, underlying dangers of employee's future turnover and fraud, while on-the-job consumption and deferred payment ncrease dependence of employees to the enterprise [12]. The domestic research on the efficiency of on-the-job consumption is less. Most of them think that under the specific background of China, the cost of compensation incentive would be too high, and the regulation therefore is an inevitable choice. Chen and others propose that the compensation control on execuives of SOEs brings about an increase of enterprise value. Under the specific background of China, compensation control is an inevitable choice in practice [13]. In the study of the relationship between media supervision and compensation of executives, Yang and Zhao prove that media supervision plays a governance role to rationalize compensation [14]. Combined with the important variables of managers' power, Wang discuss the influence of compensation structure on the enterprises' performance under different circumstances. $\mathrm{He}$ argues when managers' power are bigger, on-the-job consumption negotiates the interests between the enterprises and managers, exerting a positive influence on enterprises' performance. Although at this point the incentive cost for onthe-job consumption is higher, the results are more effective [15].

In summary, as to the effectiveness of the compensation regulation, different scholars have different conclusions from different perspectives. Therefore, there is no consensus regarding the definite cause-and-effect relationship between the regulation and enterprises' performance. As a result, analysis must be undertaken in accord with specific circumstances, so as to make a judgment.

Based on the theory and literature review, this section discusses the possible effects of compensation limit order, enriching the research on the issue of executive compensation control in SOEs. At the same time, for the government, it can make clear the effectiveness of executive compensation incentives and the compensation control, so as to provide reference for government's formulation. The state-owned enterprise performance is closely related to the development of national economy, and their executives' compensation level is tied up with the concerns of social distribution and equality by people from all walks of life and thus have a practical significance.

\section{CONCLUSIONS}

The research make an analysis on the origins and effects of compensation control on SOE executives. Most scholars believe that the executive pay may not reach its anticipated expectations, because according to the agency theory, contradiction lies between the owners and the management: control on the compensation of executives, they will seek equivalent compensation through other means such as increasing on-the-job consumption and power rent-seeking, related party transactions and other practices, leading to corruption of state-owned enterprises, which in turn bring negative influences on enterprise performance. Therefore, in the short run, due to the particularity of China's state-owned enterprise system, the compensation limit has its rationality and necessity. But in the long run, the limit are only transitional measure or a contingency in China's current environment.

\section{RECOMMENDATIONS}

In view of the problem of executive compensation of SOEs, further implications are drawn from:

\section{A. Improve the decision-making mechanism of executive compensation of SOES}

At present, the structure of China's SOEs' compensation system is simple with low degree of correlation with corporate performance (which is a problem specific of China's situation), the main reason behind which is the executive compensation decision mechanism is not thorough in SOEs, therefore, the current executive compensation system reform should focus on improving the decision-making system on compensation of SOEs' executives: First of all, various factors and forces of pay decisions should be considered comprehensively: enterprise factors, executives own factors, as well as environmental factors. Secondly, the process of compensation decision should be clarify to establish a scientific, reasonable, and detailed salary decision procedure. Finally, a scientific and rational compensation model is needed to be established.

\section{B. Improve internal governing mechanism of enterprises}

To regulate the compensation issue of executives of SOEs should take hands on internal governing mechanism. Generally speaking, the supervision mechanism of the board should be emphasized, the powers of executives should be control, and attention should be paid in the board's power in deciding compensation and in supervising executives

\section{De-administration of executives of SOES}

For a long time, the administrative selection of executives of SOEs deviates from the "fittest survival" market competition mechanism, both the board of directors and management are selected and appointed by the government, which will reduce the executives the sense of responsibility. The identity of executives of SOEs, therefore, should be clarified and at the same time, their selection should take on a 
professional managers' path of market pricing and prestige mechanism so as to realize the goal of "de-administration", and "de-officialism".

\section{$D$. Increase the degree of information disclosure on the compensation of executives in SOE}

A detailed disclosure on their compensation is to meet the need of the public's rights to be informed, and an effective measure to prevent the loss of state-owned assets and constraints the practice of executives. It can be done in two ways: on one hand, the information disclosed should be made detailed. On the other hand, relevant laws and regulations are needed to be further improved. Only in this way can we effectively prevent corruption more effective among executives.

\section{E. Implement different levels of compensation control for different types of state-owned enterprises Figures}

For executives of SOE enterprises, the "one size fits all" measure cannot be used to regulate all, instead, classified management is needed. The management for SOEs should be classified: for some large state-owned enterprises with monopoly resources, because of their administrative setting, the high barriers to entry for competitors enable them to obtain high profit easily, specific supervision institutions should be set up to monitor, and corresponding compensation control should be implemented when necessary; for profit-making state-owned enterprises, the path of market-oriented should be continued, government policy intervention should be reduced, and at the same time operating mechanism must adapt to requirements of market economy, and the selection of executives should also be on the path of professional manager market. For these part of enterprises, distinctive compensation control should be taken and even without compensation control on the executives.

\section{ACKNOWLEDGMENT}

We would like to express our thanks to this conferences organizers and press editors. Thanks very much for their time in preparing the conference and viewing our essay. In the process of the selection of topic and research, I got the kindly care, constantly encouragement and patient guidance from my tutor Gan Jiawu. He has serious attitude and strives for perfection the work style, which deeply influence and inspire me. Now, I would like to express my sincere thanks and high respect to he.

\section{REFERENCES}

[1] Z.S. Huang, "Fair preference, status ambiguity and salary regulation of state-owned enterprise managers," Contemporary economic science, 2009.

[2] X.W. Wang, "Research on executive incentive of state owned enterprises under salary control" University of Shandong, 2014, pp. 90121

[3] H.L. Wan and X.Y. Chen, "Governance environment, enterprise rentseeking and transaction cost -- Empirical Evidence Based on non productive expenditure of Chinese Listed Companies," Economics (quarterly), 2010, pp. 553-570.

[4] M.C. Jensen, "Agency Costs of Cash Flow.Corporate Finance and Takeover," American Economic Review, 1976, pp. 323-329.

[5] D.H. Chen, X.Y. Chen and H.L. Wan, "Salary regulation and on-the-job consumption in state owned enterprises," Economic Research, 2005 , pp. 92-101.

[6] Y.F. Shen and P.G. Li, "The study of the relationship between government salary limit and executive pay, performance and luck in state owned enterprises," China Industrial Economics 2010, pp. 130139.

[7] C.B. Wang and X.Y. Zhu, "Research on the relationship between executive compensation and company performance and government pay limit order," Statistics and Decision Making, 2012, pp. 161-164.

[8] G.W. Xu. "Research on top management incentive mechanism of state owned enterprises under government control" University Of Chongqing, 2012

[9] X.X. Xu, "Forefront of enterprise executives corruption research," Foreign Economy And Management, 2012, pp. 3-80.

[10] D.G. Chen and S.K. Liang, "On the job consumption, equity balance and its economic consequences: Empirical Evidence from Chinese Listed Companies," Journal of Shanghai Lixin University of Commerce, 2010, pp. 9, 27, 97.

[11] Rajan, G. Raghuram, and J. Wulf, "Are Perks Purely Managerial Excess?” Journal of Financial Economics, 2006, pp. 1-33.

[12] Henderson, M. Todd and J. Spindler, "Corporate Heroin: A Defense of Perks, Executive Loans, and Conspicuous Consumption," Georgetown Law Journal, 2005, pp. 67-78.

[13] J.H. Chen, S.S. Sui and J.J. Wang, "Does Salary Regulation reduce the incentive efficiency of managers?-Analysis of compensation structure model based on the cater effect," Southern Economy, 2011, pp. 38, 46, 80

[14] D.M. Yang and C. Zhao, "Media supervision, media governance and executive compensation," Economic Research, 2012, pp. 116-126.

[15] J. Song, "Research on the reform path and mode of executive compensation system in state owned enterprises," Press Of The Economic Science, 2013, pp. 71-80. 